\title{
Role of Calcium Channels in the Protective Effect of Hydrogen Sulfide in Rat Cardiomyoblasts
}

\author{
Daniele Avanzato ${ }^{a, f} \quad$ Annalisa Merlino ${ }^{b, f}$ Sabina Porrera ${ }^{b}$ Rui Wang ${ }^{c}$ \\ Luca Munaron a,d,e Daniele Mancardi ${ }^{\mathrm{b}, \mathrm{c}}$
}

${ }^{a}$ Department of Life Sciences and Systems Biology, University of Torino, Torino, ${ }^{b}$ Department of Clinical and Biological Sciences, University of Torino, Torino, Italy, 'Cardiovascular and Metabolic Research Unit, Lakehead University, Thunder Bay, ON, Canada, ${ }^{\mathrm{d}}$ Center for Complex Systems in Molecular Biology and Medicine (SysBioM), University of Torino, Torino, eNanostructured Interfaces and Surfaces Centre of Excellence (NIS), University of Torino, Torino, Italy; fthese authors contributed equally

\section{Key Words}

Hydrogen sulfide $\cdot$ Oxidative stress $\bullet$ Voltage-operated calcium channels $\bullet$ Cardiomyoblasts $•$ Calcium signaling

\begin{abstract}
Background: Hydrogen sulfide contributes to the reduction of oxidative stress-related injury in cardiomyocytes but the underlying mechanism is still unclear. Aims: Here we investigated the role of voltage-operated calcium channels (VOCCs) as mediators of the beneficial effect of $\mathrm{H}_{2} \mathrm{~S}$ against oxidative stress in cultured rat cardiomyoblasts (H9c2). Methods: Intracellular calcium signals were measured by fluorimetric live cell imaging and cell viability by colorimetric assay. Results: Treatment with $\mathrm{H}_{2} \mathrm{~S}$ donor (NaHS $\left.10 \mu \mathrm{M}\right)$ or Nifedipine $(10 \mu \mathrm{M})$ decreased resting intracellular calcium concentration $[\mathrm{Ca}]_{i}$, suggesting that L-type VOCCs are negatively modulated by $\mathrm{H}_{2} \mathrm{~S}$. In the presence of Nifedipine $\mathrm{H}_{2} \mathrm{~S}$ was still able to lower [Ca] $]_{i}$, while coincubation with Nifedipine and $\mathrm{Ni}^{2+} 100 \mu \mathrm{M}$ completely prevented $\mathrm{H}_{2} \mathrm{~S}$-dependent $[\mathrm{Ca}]_{i}$ decrease, suggesting that both L-type and T-type VOCCs are inhibited by $\mathrm{H}_{2} \mathrm{~S}$. In addition, in the same experimental conditions, $\mathrm{H}_{2} \mathrm{~S}$ triggered a slow increase of $[\mathrm{Ca}]_{i}$ whose molecular nature remains to be clarified. Pretreatment of H9c2 with NaHS $(10 \mu \mathrm{M})$ significantly prevented cell death induced by $\mathrm{H}_{2} \mathrm{O}_{2}$. This effect was mimicked by pretreatment with L-Type calcium channel inhibitor Nifedipine $(10 \mu \mathrm{M})$. Conclusions: The data provide the first evidence that $\mathrm{H}_{2} \mathrm{~S}$ protects rat cardiomyoblasts against oxidative challenge through the inhibition of L-type calcium channels.
\end{abstract}




\section{Introduction}

Oxidative stress is the principal cause of cell death during ischemia/reperfusion (I/R) processes [1-5]. In fact, restoration of blood flow and oxygen supply generates reactive oxygen species (ROS) that trigger apoptosis and necrosis phenomena [6-8]. Cardiomyocytes face this occurrence during the so-called myocardial infarction consisting of I/R in the cardiac tissue. ROS form during re-oxygenation of the infarcted tissue and lead to the activation of a wide range of reaction cascades resulting in pro-apoptotic and necrotic stimuli $[9,10]$. Membranes integrity is compromised by phospholipids oxidation leading to uncontrolled ionic permeability [8]. Ionic conductance can also be affected by the direct action of ROS on channel proteins [11]. The effect of such processes is, among the others, an increase $\mathrm{Ca}^{2+}$ permeability with a consequent rise of intracellular calcium levels. It is not clear, however, whether voltage-operated calcium channels (VOCC) plays a role in myocardial I/R injury [12]. Consistently, in vitro experimental models confirmed the efficacy of $\mathrm{H}_{2} \mathrm{~S}$ donors in protecting cultured cardiomyocytes against hypoxia/reoxygenation and oxidative challenges [13]. Several mechanisms have been proposed to explain such outcome but literature on this topic is still controversial and laconical [14].

On the other hand, what appears unequivocal is that $\mathrm{H}_{2} \mathrm{~S}$ can regulate the activity of ion channels either in the outer membrane or in intracellular organelles such as mitochondria [15]. The first report on the effect of $\mathrm{H}_{2} \mathrm{~S}$ on ion channels originally appeared more than one decade ago [16] and, since then, the modulation of plasmalemma calcium channels by $\mathrm{H}_{2} \mathrm{~S}$ has been shown [17]. In cardiomyocytes, two predominant calcium channels are expressed: L-type and T-Type. L-type $\mathrm{Ca}^{2+}$ channels are ubiquitously expressed representing the principal mediator for excitation-contraction coupling in the heart. Concurrently, T-type $\mathrm{Ca}^{2+}$ channels are selectively expressed depending on species, cardiac region and pathological states. In I/R injury, for instance, calcium channels activity is altered to mediate post-ischemic deleterious effects [18]. In fact, one of the most detrimental factors of interrupting and restoring blood supply to the heart is the unbalanced change in calcium homeostasis [19]. Calcium overload in post-ischemic cardiomyocytes is the leading cause of cell death either through apoptosis or necrosis [20]. Intracellular calcium concentration is finely regulated through the control of flux from the extracellular compartment and from internal reservoirs. Alteration of this subtle balance triggers a plethora of effects and $\mathrm{H}_{2} \mathrm{~S}$ can, indeed, cause physiological changes of calcium permeability. In our previous reports we showed that the administration of NaHS induces a significant increase in intracellular calcium in endothelial cells from excised rat aorta [21]. On the other hand, in pancreatic beta cells NaHS inhibited L-type VOCCs [22].

In the present study we investigate the role of $\mathrm{H}_{2} \mathrm{~S}$ in the regulation of VOCCs and the related functional effects on the cardiomyoblast cell line $\mathrm{H} 9 \mathrm{c} 2$.

\section{Materials and Methods}

\section{Cell cultures}

Rat embryonic ventricular myocytes cells line H9c2 were obtained from American Collection of Cell Cultures (ATCC ${ }^{\circledR}$ CRL-1446 ${ }^{\text {tw }}$ Milan Italy). Cells were maintained in Dulbecco's modified Eagle's medium (DMEM) supplemented with 10\% fetal calf serum (FCS), $100 \mu \mathrm{g} / \mathrm{mL}$ gentamycin and $4 \mathrm{mM} \mathrm{l-glutamine,} \mathrm{and}$ maintained in normal culture conditions $\left(37^{\circ} \mathrm{C}\right.$, saturated humidity atmosphere at $95 \%$ air $\left./ 5 \% \mathrm{CO}_{2}\right)$. Before reaching confluence, cells were sub-cultured onto $25 \mathrm{~cm}^{2}$ culture flasks and used at passages 2-7.

\section{H2S donor and Stressor compound}

Sodium Hydrogen Sulfide (NaHS) and Hydrogen peroxide $\left(\mathrm{H}_{2} \mathrm{O}_{2}\right)$ were purchased from Sigma Aldrich and freshly prepared on the day of the experiments by dissolving the salt in the physiological solution (TS) for calcium imaging experiments and/or in the culturing medium for MTT assay. 


\section{Cell viability assay}

The cell viability was analyzed using a methylthiazol tetrazolium (MTT) assay. The colorimetric assay is based on the ability of live cells to reduce the yellow MTT reagent (Sigma Aldrich, Italy) to a purple formazan product. H9c2s were seeded in 96-well plates at a cellular density of $0.5 \times 10^{4}$ cell/well. Cells were starved overnight with $1 \%$ FCS in order to increase cell cycle synchronization. The following day H9c2 were treated for 1 hour with different concentrations of NaHS and/or $10 \mu \mathrm{M}$ Nifedipine alone. Afterward, cells were exposed to $50 \mu \mathrm{M} \mathrm{H}_{2} \mathrm{O}_{2}$ (3 hour) in order to induce oxidative stress. A total of $100 \mu \mathrm{l}$ of MTT solution was added to each well, and the cells were then incubated at $37^{\circ} \mathrm{C}, 5 \% \mathrm{CO}_{2}$ for $4 \mathrm{~h}$. After incubation, MTT was aspirated and $100 \mu \mathrm{l} /$ well DMSO was added. Subsequently, the cell viability was assessed by measuring the absorbance at $570 \mathrm{~nm}$.

\section{Calcium imaging}

For ratiometric $[\mathrm{Ca}]_{\mathrm{i}}$ measurements on $\mathrm{H} 9 \mathrm{c} 2$, cells were loaded with Fura-2/AM as previously described [1]. [Ca $]_{i}$ was expressed as a ratio (R) of emitted fluorescence corresponding to excitation wavelengths of $340 \mathrm{~nm}$ and $380 \mathrm{~nm}$.

High-potassium solution (HK) was prepared as follows: $\mathrm{NaCl}(118 \mathrm{mM}), \mathrm{KCl}(40 \mathrm{mM}), \mathrm{CaCl}_{2}(2 \mathrm{mM})$, $\mathrm{MgCl}_{2}(1 \mathrm{mM})$, glucose $(5.5 \mathrm{mM})$, Hepes (5 mM), and $\mathrm{NaOH}$ to $\mathrm{pH} 7.35$.

During the experiments, H9c2 were maintained in standard Tyrode solution (TS) of the following composition (in mmol/L): $\mathrm{NaCl}, 154 ; \mathrm{KCl}, 4 ; \mathrm{CaCl}_{2}, 2 ; \mathrm{MgCl}_{2}, 1$; $\mathrm{HEPES}$, 5; glucose, 5.5; and $\mathrm{NaOH}$ (pH 7.35); for experiments in calcium-free conditions, the external solution was modified omitting the $\mathrm{CaCl}_{2}$ salt from the formulation and adding the $\mathrm{Ca}^{2+}$ chelator EGTA $(5 \mathrm{mmol} / \mathrm{L})$.

The experiments were performed at room temperature. Amplitude of resting $[\mathrm{Ca}]_{\mathrm{i}}$ decrease was evaluated as the difference between $[\mathrm{Ca}]_{\mathrm{i}}$ before treatment and the minimum $\mathrm{R}$ value measured during treatment. $[\mathrm{Ca}]_{\mathrm{i}}$ increase was evaluated as the difference between the maximal $[\mathrm{Ca}]_{\mathrm{i}}$ value reached during the treatment (peak) and resting $[\mathrm{Ca}]_{i}$ before treatment. In calcium imaging experiments with $\mathrm{H}_{2} \mathrm{O}_{2}$, the slope of $[\mathrm{Ca}]_{\mathrm{i}}$ increase during the treatment was evaluated by the use of IgorPro software (Wavemetrics, USA). Any alteration of Fura-2/AM functionality due to $\mathrm{H}_{2} \mathrm{O}_{2}$ was excluded by separately analyzing the emission corresponding to $340 \mathrm{~nm}$ and $380 \mathrm{~nm}$ excitation.

Data analysis and statistics

For Fura-2 ratiometric measurements, single cells were selected for each image sequence with Metafluor software (Universal Imaging Corporation).

Calcium imaging offline analyses were performed using IgorPro software. Statistical significance of all experiments was evaluated with Kaleidagraph software (Synergy Software, USA). We used nonparametric tests (Wilcoxon) for the entire statistical analysis in this work since not all the data were normally distributed.

\section{Results}

H2S inhibits L-type calcium channels in H9c2

Acute application of NaHS (1-100 $\mu \mathrm{M})$ to H9c2 cells bathed in Tyrode Standard (TS) physiological extracellular solution induced a large and reversible decrease of resting intracellular calcium ([Ca $]_{\mathrm{i}}$ ) in $60 \%$ of tested cells ("NaHS-sensitive cells"): Figure $1 \mathrm{~A}$ shows a representative response to $10 \mu \mathrm{M}$ NaHS. Interestingly, NaHS-sensitive cells had a higher resting $[\mathrm{Ca}]_{\mathrm{i}}$ compared to insensitive cells $(\mathrm{R}=0.52 \mathrm{vs.} 0.48$, as shown in Figure $1 \mathrm{~B}$, grey bars).

When cells were exposed to high-potassium (HK) extracellular solution ( $40 \mathrm{mM} \mathrm{KCl}$, see methods) in order to depolarize cell membrane and to activate all the VOCCs, the effect of $\mathrm{NaHS}$ was detected in a significantly higher subpopulation of cells $(\geq 80 \%)$. In HK solution, as in the case of TS-bathed cells, NaHS-sensitive population displays higher resting $[\mathrm{Ca}]_{\mathrm{i}}$ than insensitive cells ( $\mathrm{R}=0.56$ vs. 0.49 , Fig. $1 \mathrm{~B}$, black bars).

In particular, resting [Ca $]_{\mathrm{i}}$ decrease triggered by 1,10 and $100 \mu \mathrm{M}$ NaHS was observed respectively in $68.7 \%, 78,0 \%$ and $78,5 \%$ of the cells. 


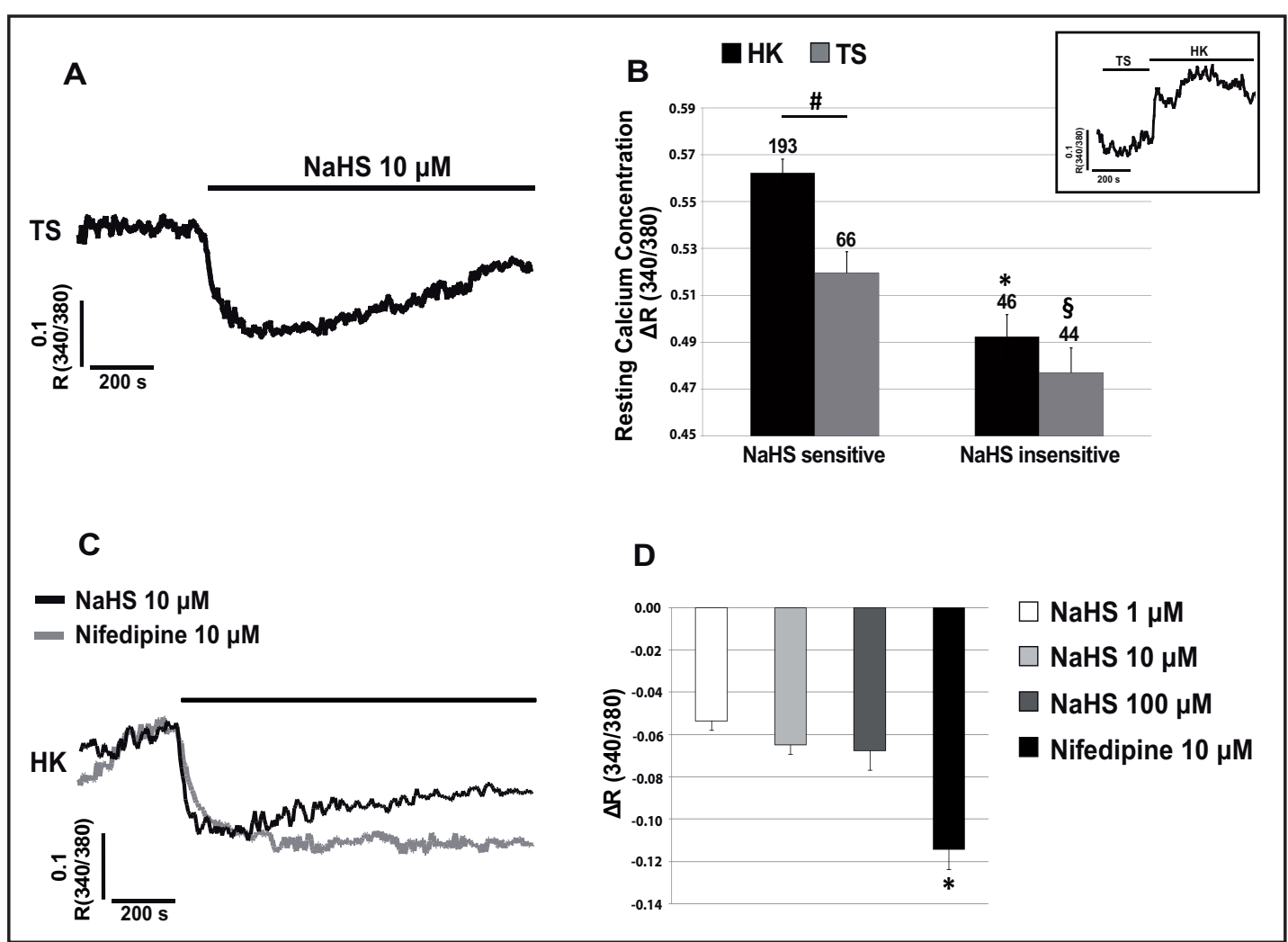

Fig. 1. Effect of NaHS on resting $[\mathrm{Ca}]_{\mathrm{i}}$ in $\mathrm{H} 9 \mathrm{c} 2$. Representative trace showing the decrease in resting $[\mathrm{Ca}]_{\mathrm{i}}$ induced by acute application of $10 \mu \mathrm{M}$ NaHS in cells bathed in a physiological extracellular solution (TS) (A). Resting [Ca $]_{i}$ levels in cells sensitive or not to NaHS treatment (NaHS-sensitive and NaHS-insensitive) bathed in high potassium solution (HK, black bars) or in physiological extracellular solution (TS, grey bars). Cell numbers are reported on the top of histogram. Wilcoxon test. HK versus TS in NaHS-sensitive cells $\# \mathrm{p}<0.01$ (a representative trace of the acute effect of HK perfusion is shown in the inset of figure 1B). NaHSsensitive versus NaHS-insensitive cells in HK solution ${ }^{*} \mathrm{p}<0.001$. NaHS-sensitive versus NaHS-insensitive in TS solution $\S p<0.001$ (B). Representative traces showing the decrease in resting [Ca $]_{\mathrm{i}}$ induced by acute application of $10 \mu \mathrm{M}$ NaHS (black line) or $10 \mu \mathrm{M}$ Nifedipine (grey line) in cells bathed in HK solution (C). Quantification of $[\mathrm{Ca}]_{\mathrm{i}}$ decrease induced in HK-bathed cells by three NaHS concentrations (1-10-100 $\left.\mu \mathrm{M}\right)$ or $10 \mu \mathrm{M}$ Nifedipine (D). Wilcoxon test. NaHS (1-10-100 $\mu \mathrm{M})$ versus Nifedipine $10 \mu \mathrm{M} * \mathrm{p}<0.001$. Data are expressed as the mean \pm S.E.M.

Acute perfusion with $10 \mu \mathrm{M}$ Nifedipine, a selective blocker of L-type calcium channels, induced a resting $[\mathrm{Ca}]_{\mathrm{i}}$ decrease in $100 \%$ of $\mathrm{H} 9 \mathrm{c} 2 \mathrm{~s}$ bathed in HK solution: the amplitude of the effect was higher than that observed upon NaHS treatment (Fig. 1C and 1 D).

Resting [Ca] $]_{i}$ of NaHS-sensitive cells pretreated with Nifedipine was significantly lower than that measured in cells untreated with the blocker. On the other hand, no significant differences were detected between NaHS-insensitive cells treated or untreated with Nifedipine (Fig. 2A) in agreement with an earlier report [23]. In particular, our data suggest that $\mathrm{H}_{2} \mathrm{~S}$-sensitive L-type VOCCs are active in resting conditions in a subpopulation of H9c2 cells.

\section{H2S inhibits T-type Calcium Channels}

Interestingly, in cells pre-incubated with $10 \mu \mathrm{M}$ Nifedipine, acute application of 10 $\mu \mathrm{M}$ NaHS was still able to induce a slow, although significant, reduction of resting [Ca $]_{\mathrm{i}}$ in a percentage lower than that observed in Nifedipine-untreated cells (Fig. 2B and Fig. 3A). Since T-type VOCC are expressed in cardiomyocytes [24], we decided to investigate their putative role as a target for NaHS in $\mathrm{H} 9 \mathrm{c} 2$ cells under resting conditions. 
Fig. 2. Effect of inhibition of L-type calcium channels. Histogram reporting the resting $[\mathrm{Ca}]_{\mathrm{i}}$ levels in NaHS-sensitive and NaHSinsensitive HK-bathed cells preincubated or not with $10 \mu \mathrm{M}$ Nifedipine. (A). NaHSinduced $[\mathrm{Ca}]_{\mathrm{i}}$ decrease in HK-bathed cells pre-incubated with $10 \mu \mathrm{M}$ Nifedipine (white bar) or not (black bar) (B). Data are expressed as the mean \pm S.E.M. Wilcoxon test $* \mathrm{p}<0.001$.

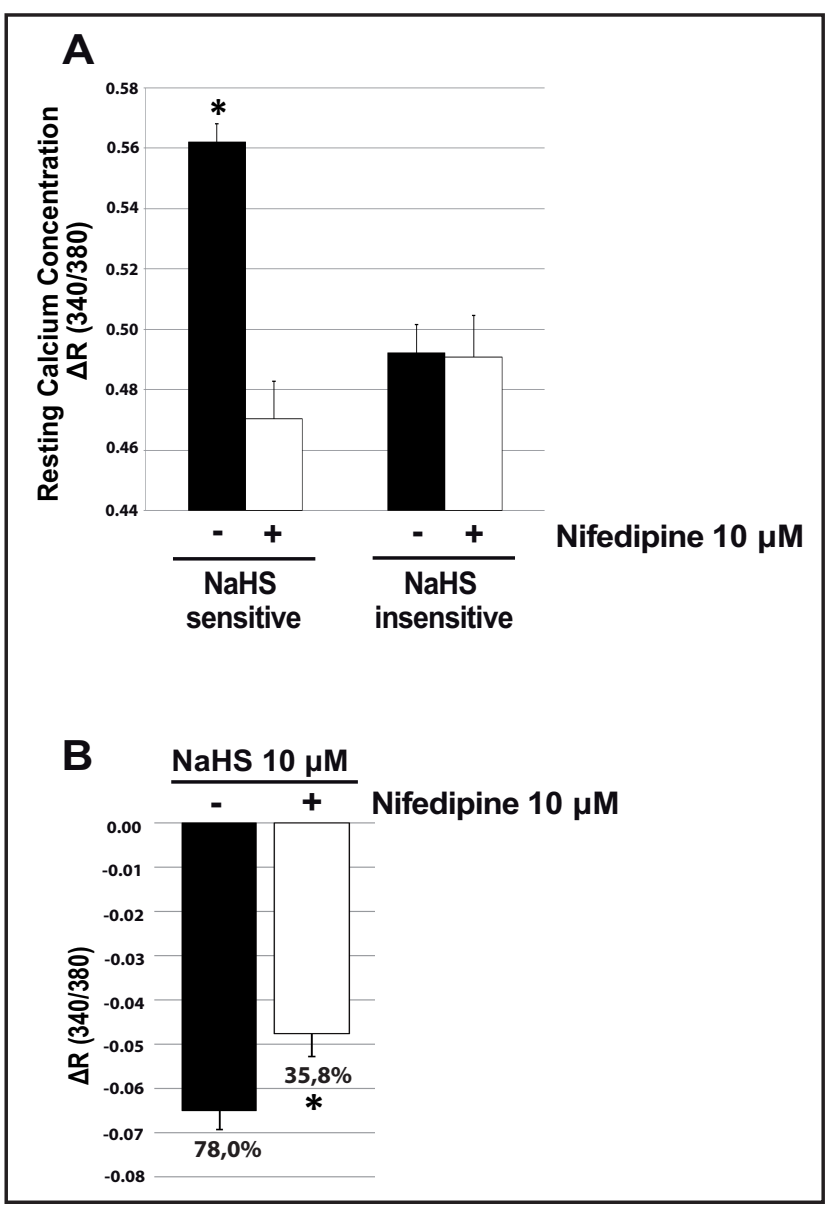

In two distinct sets of experiments we used two different $\mathrm{Ni}^{2+}$ concentrations, $30 \mu \mathrm{M}$ and $100 \mu \mathrm{M}$, respectively acting on only subtype $\alpha 1 \mathrm{H}$ or on the totality of T-type channels ( $\alpha 1 \mathrm{H}, \mathrm{G}$ and I) [25].

In cells pretreated with Nifedipine and $30 \mu \mathrm{M} \mathrm{Ni}^{2+}$ acute application of $10 \mu \mathrm{M}$ NaHS was still able to decrease resting [Ca $]_{\mathrm{i}}$ in $90 \%$ of the cells, but the effect was lower than that observed in cells pre-treated with Nifedipine only (Fig. 3A).

On the other hand, in cells pretreated with Nifedipine and $100 \mu \mathrm{M} \mathrm{Ni}^{2+}$, acute application of $10 \mu \mathrm{M}$ NaHS completely failed to decrease resting [Ca] ${ }_{\mathrm{i}}$ levels (Fig. 3A). Accordingly, cells pretreated with both $10 \mu \mathrm{M}$ Nifedipine and $100 \mathrm{Ni}^{2+}$ showed resting [Ca] levels significantly lower than untreated cells. Switching to free calcium extracellular medium did notaffect resting $[\mathrm{Ca}]_{i}$ (Fig. 3B). Furthermore, acute application of $10 \mu \mathrm{M}$ NaHS induced a $[\mathrm{Ca}]_{\mathrm{i}}$ increase in $100 \%$ of cells pretreated with both Nifedipine and $100 \mu \mathrm{M} \mathrm{Ni}^{2+}$. The amplitude of the response was higher in TS solution then in HK solution and resulted drastically reduced in free-calcium extracellular medium (Fig. 3C, 3D).

H2S prevents $\mathrm{H} 9 \mathrm{c} 2$ death induced by $\mathrm{H} 2 \mathrm{O} 2$ via L-type calcium channels

$\mathrm{H} 9 \mathrm{c} 2$ cells were challenged for 3 hours with $50 \mu \mathrm{M} \mathrm{H}_{2} \mathrm{O}_{2}$ in order to promote oxidative stress-induced cell death (59\% cell survival). Pre-incubation for 1 hour with different concentrations of NaHS $(1,10,100 \mu \mathrm{M})$ enhanced cell survival of $55 \pm 3 \%, 58 \pm 2 \%$ and $78 \pm 3 \%$ respectively (black bar in Fig. 4). Similar results were obtained when NaHS was used as a post-conditioning agent, in which cells were challenged with $\mathrm{H}_{2} \mathrm{O}_{2}(50 \mu \mathrm{M}, 1$ hour $)$ and then treated with NaHS (data not shown).

All the concentrations tested were able to protect the cells against $\mathrm{H}_{2} \mathrm{O}_{2}$ inducedapoptosis (Fig. 4, left panel). $\mathrm{H}_{2} \mathrm{~S}$ per se did not significantly affect cell viability (not shown). 


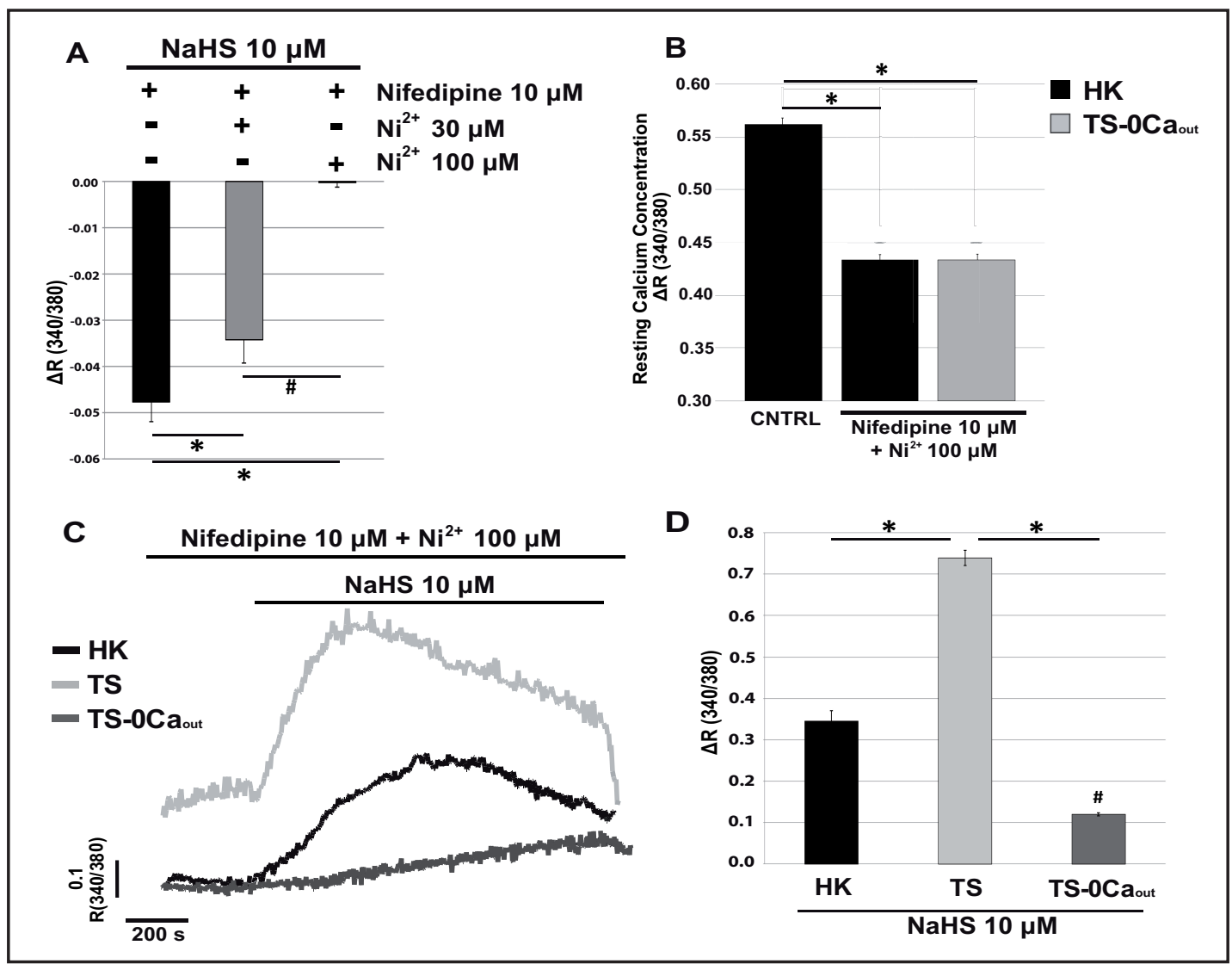

Fig. 3. Effect of inhibition of L- and T-type calcium channels. Histogram reporting the amplitude of NaHSinduced $[\mathrm{Ca}]_{\mathrm{i}}$ decrease in cells pre-incubated with $10 \mu \mathrm{M}$ Nifedipine and $30 \mu \mathrm{M} \mathrm{Ni}^{2+}$ or $100 \mu \mathrm{M} \mathrm{Ni}^{2+}(\mathrm{A})$. Resting [Ca $]_{i}$ levels in cells preincubated with $100 \mu \mathrm{M}$ Nickel and $10 \mu \mathrm{M}$ Nifedipine and bathed in HK or free calcium-TS solution. CNTRL is resting $[\mathrm{Ca}]_{\mathrm{i}}$ in not-preincubated cells (B). Representative traces showing NaHS-induced $[\mathrm{Ca}]_{\mathrm{i}}$ increase in cells pre-incubated with $10 \mu \mathrm{M}$ Nifedipine and $100 \mu \mathrm{M} \mathrm{Ni}^{2+}$; black trace: HKbathed cells, light gray trace: TS-bathed cells and dark grey: TS-calciumf-ree-bathed cells (C). [Ca] increase has been quantified measuring the peak amplitude for each condition (D). Wilcoxon test. ${ }^{*} \mathrm{p}<0.001$. Data are expressed as the mean \pm S.E.M.

Fig. 4. Effect of NaHS on cell viability upon oxidative stress. Left panel. Cell survival after 1 hour pre-incubation different NaHS concentrations followed by oxidative challenge with $50 \mu \mathrm{M} \mathrm{H}_{2} \mathrm{O}_{2}$. Right panel. Cell survival after 1 hour co-incubation with different NaHS concentrations and/or $10 \mu \mathrm{M}$ Nifedipine alone followed by oxidative challenge with $50 \mu \mathrm{M} \mathrm{H}_{2} \mathrm{O}_{2}$. Wilcoxon test. CTRL (black box) is significantly different compared to all other conditions tested $(* *, p<0,001) . N=3$ Data are expressed as the mean \pm S.E.M.

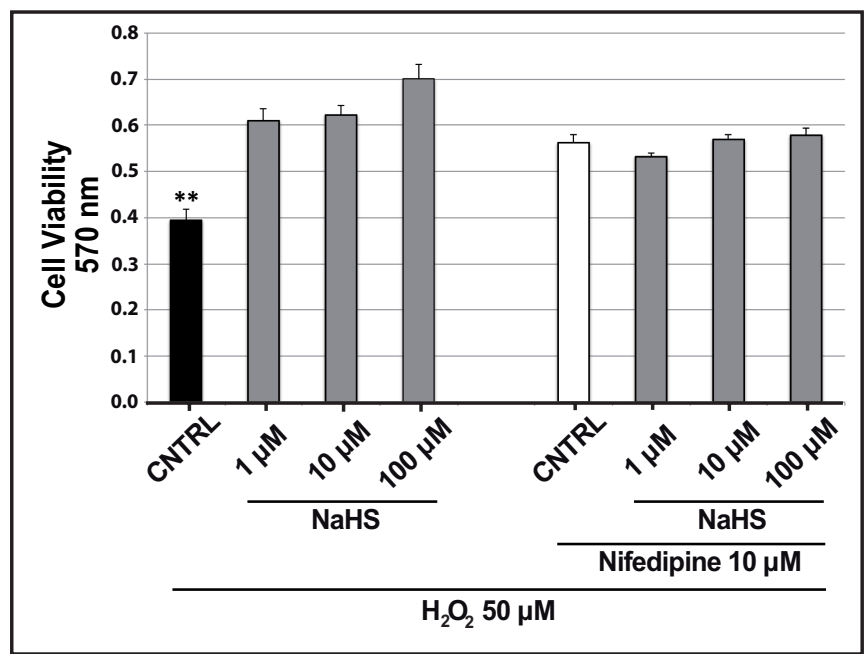

Similarly to NaHS, pre-incubation with $10 \mu \mathrm{M}$ Nifedipine protected cells from $\mathrm{H}_{2} \mathrm{O}_{2}$ challenge (white bar in Fig. 4). Interestingly, no additive effect could be observed when cells were 


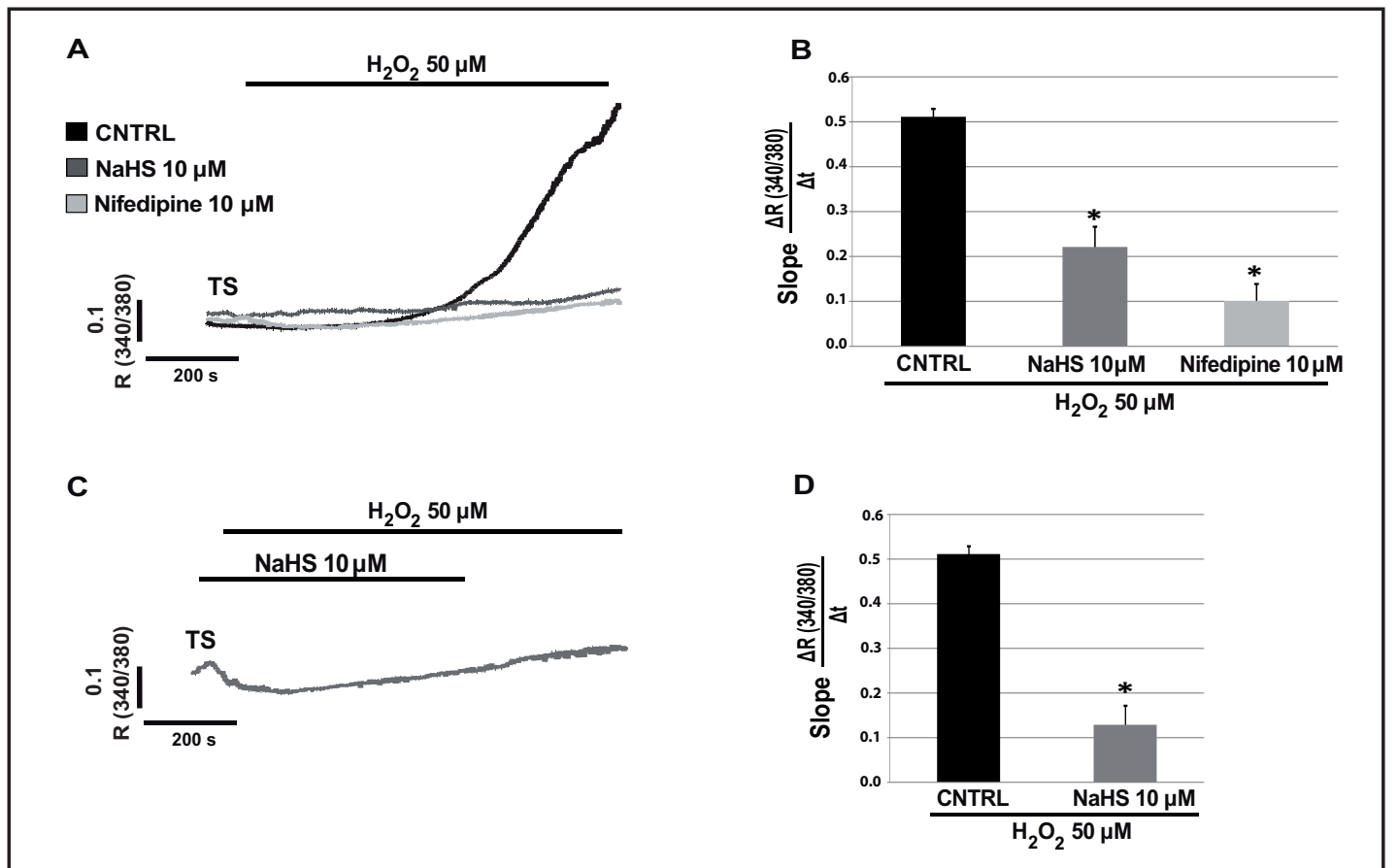

Fig. 5. Effects of $\mathrm{H}_{2} \mathrm{O}_{2}$ on $[\mathrm{Ca}]_{\mathrm{i}}$. Representative traces showing the effect of $50 \mu \mathrm{M} \mathrm{H}_{2} \mathrm{O}_{2}$ perfusion on [Ca $]_{\mathrm{i}}$ in control cells (black trace), $10 \mu \mathrm{M}$ NaHS-preincubated cells (dark grey) and $10 \mu \mathrm{M}$ Nifedipine-preincubated cells (light grey) (A). Histogram showing a quantification of the slope in $[\mathrm{Ca}]_{\mathrm{i}}$ increase. $* \mathrm{p}<0.001$ versus CNTRL. (B). Representative trace and quantification of [Ca $]_{\mathrm{i}}$ increase induced by $50 \mu \mathrm{M} \mathrm{H}_{2} \mathrm{O}_{2}$ in cells in which NaHS was perfused starting from 10 minutes after oxidative challenge ( $C$ and D). Wilcoxon test. ${ }^{*} \mathrm{p}<0.001$ versus CNTRL. Data are expressed as the mean \pm S.E.M.

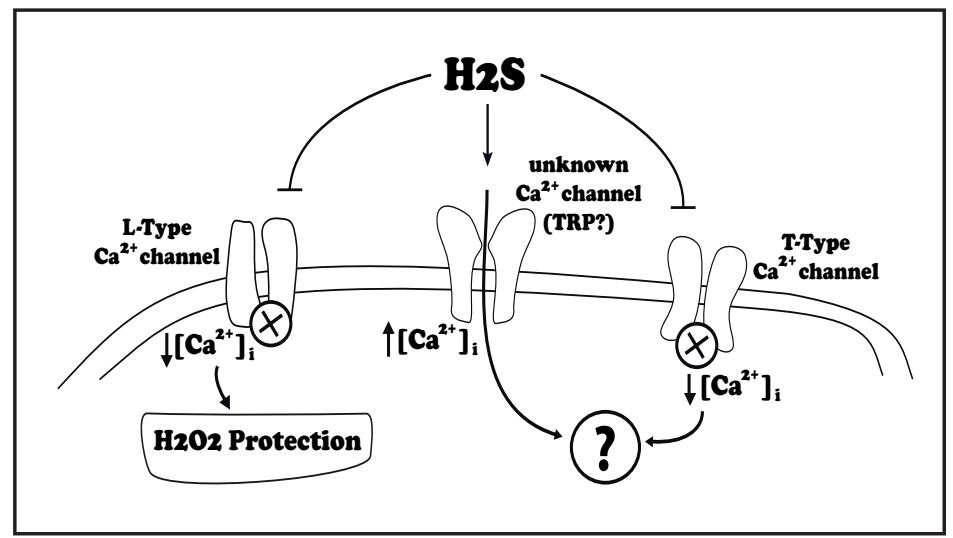

Fig.6. Scheme reviewing the main conclusions of the work.

co-incubated with $10 \mu \mathrm{M}$ Nifedipine and NaHS $(1 \mu \mathrm{M}, 10 \mu \mathrm{M}$ and $100 \mu \mathrm{M})$, suggesting a convergence between L-type calcium channels and $\mathrm{H}_{2} \mathrm{~S}$-mediated effects (Fig. 4, right panel).

We performed calcium imaging experiments in order to evaluate $[\mathrm{Ca}]_{\mathrm{i}}$ changes during oxidative stress (Fig. 5). Acute perfusion with $50 \mu \mathrm{M} \mathrm{H}_{2} \mathrm{O}_{2}$ induced a delayed and irreversible $[\mathrm{Ca}]_{\mathrm{i}}$ increase, detectable starting from 30-40 minutes of $\mathrm{H}_{2} \mathrm{O}_{2}$ perfusion. Pre-incubation with either $10 \mu \mathrm{M}$ NaHS or $10 \mu \mathrm{M}$ Nifedipine largely prevented $\mathrm{H}_{2} \mathrm{O}_{2}$-induced [Ca] $]_{\mathrm{i}}$ increase (Fig. $5 \mathrm{~A}$ and $5 \mathrm{~B})$. The same protective effect against the large $[\mathrm{Ca}]_{\mathrm{i}}$ increase was observed when 10 $\mu \mathrm{M}$ NaHS was perfused starting from 10 minutes after oxidative challenge (Fig. 5 C and D). 


\section{Discussion}

Reoxygenation-driven oxidative stress is responsible for post-ischemic cell death. Restoration of blood supply after ischemia triggers massive tissue damage leading to impaired organ function. Myocardial and cerebral ischemia are estimated to be the two major causes of death in the western countries with a profound socio-economic burden. Therefore, the comprehension of mechanisms underlying this process and the investigation of possible treatments appears to be of paramount importance.

Hydrogen sulfide is an important gasotransmitter [26]. Although several reports confirm the efficacy of $\mathrm{H}_{2} \mathrm{~S}$ in reducing reoxygenation and reperfusion injury in the myocardium and a large body of literature has been dedicated to putative mechanisms [27], we still lack pharmacological targets that can translate these basic research findings into clinical and therapeutic applications. We selected an immortalized cardiomyoblast cell line (H9c2) that represents one of the few valid in vitro models to perform experiments on non-primary cardiomyocytes. Single cell calcium imaging measurements led us to identify two subpopulations of cells with different responses to acute stimulation with $10 \mu \mathrm{M}$ NaHS (Fig. 1). In the majority of cells (60\%) NaHS induced a significant decrease of basal [Ca] ${ }_{i}$ and, in the same population, resting $[\mathrm{Ca}]_{i}$ was higher than that observed in non-sensitive cells. The percentage of responsive cells increased upon pre-activation of voltage-dependent $\mathrm{Ca}^{2+}$ channels by high extracellular $\mathrm{K}^{+}$concentration (Fig. 1B). This evidence suggests than NaHS inhibits VOCCs constitutively open in a subpopulation of non-stimulated H9c2 cells. Accordingly, L-type $\mathrm{Ca}^{2+}$ channel blocker Nifedipine induced a larger decrease in resting [Ca ${ }_{\mathrm{i}}$ in the totality of cells (Fig. 1C-D). Furthermore, resting [Ca $]_{i}$ levels are higher in $\mathrm{H}_{2} \mathrm{~S}$-sensitive cells compared to $\mathrm{H}_{2} \mathrm{~S}$-insensitive and Nifedipine pre-treated cells (Fig. 2A).

Nevertheless, L-type is not the only $\mathrm{Ca}^{2+}$ channel type sensitive to $\mathrm{H}_{2} \mathrm{~S}$. Upon Nifedipine pre-treatment, NaHS was still able to induce [Ca $]_{i}$ reduction (Fig. 2B and Fig. 3A): this effect was completely prevented by co-incubation with both Nifedipine and $\mathrm{Ni}^{2+} 100 \mu \mathrm{M}$, that blocks all T-type VOCCs (Fig. 3B). There have been previous reports about the T-type channels activation by $\mathrm{H}_{2} \mathrm{~S}$ in neurons [28-30]; on the other hand, Elies et al. reported an inhibitory effect with high doses of NaHS on Cav3.2-overexpressing HEK cells [31]. This is the first preliminary evidence that $\mathrm{H}_{2} \mathrm{~S}$ negatively modulates endogenously expressed T-type $\mathrm{Ca}^{2+}$ channels in myoblast cell line.

Interestingly, when both L- and T-type channels are blocked, NaHS promoted a significant increase in $[\mathrm{Ca}]_{\mathrm{i}^{*}}$ The response was, however, completely prevented in calcium free extracellular medium, suggesting a putative mediation of voltage-independent $\mathrm{Ca}^{2+}$ influx (Fig. 3C). These findings confirm our previous results obtained on endothelial cells in which we observed a similar effect due to the activation of voltage-independent calcium channels [32].

At least two different, and possibly coexisting mechanisms, could be responsible for this calcium flux through the plasma membrane of $\mathrm{H} 9 \mathrm{c} 2$ : the activation of voltage independent calcium-permeable channels as well as a modulation of sodium-calcium exchangers activity.

Among voltage-independent calcium channels, some members of transient receptor potential (TRP) channel family are expressed and functional in H9c2 cells and are proposed to play a role in cardiac hypertrophy and arrhythmia [33-35].

The other possible mechanism underlying $\mathrm{H}_{2} \mathrm{~S}$-induced calcium inflow can bypass the activation of calcium channels and involve a role for exchangers. In intact endothelium of excised rat aorta, $\mathrm{H}_{2} \mathrm{~S}$ triggers a $\mathrm{Ca}^{2+}$ influx driven by the reverse-mode $\left(3 \mathrm{Na}^{+}\right.$out $/ 1 \mathrm{Ca}^{2+}$ in $)$ of the sodium-calcium exchanger (NCX) and by $\mathrm{K}_{\text {ATP }}$ channels [21]. It could be interesting to investigate a similar role of NCX in $\mathrm{H} 9 \mathrm{c} 2$ cells.

While the functional role of T-type inhibition in $\mathrm{H} 9 \mathrm{c} 2$ cells remains unknown, the negative regulation of L-type channels by $\mathrm{H}_{2} \mathrm{~S}$ appears to be involved in cytoprotection against oxidative stress. Indeed, $\mathrm{H}_{2} \mathrm{~S}$ donor and Nifedipine are both effective to prevent $\mathrm{H} 9 \mathrm{c} 2$ death induced by $\mathrm{H}_{2} \mathrm{O}_{2}$ (Fig. 4). Oxidation by peroxide leads to an irreversible [Ca] $]_{i}$ increase significantly prevented by either NaHS or Nifedipine pre-treatment (Fig. 5). These data 
strongly suggest that the inhibition of L-type channels by $\mathrm{H}_{2} \mathrm{~S}$ could help H9c2 to maintain low the $[\mathrm{Ca}]_{\mathrm{i}}$ levels during oxidative stress induced by $\mathrm{H}_{2} \mathrm{O}_{2}$, eventually improving cell survival. It is worth noting that L-type $\mathrm{H}_{2} \mathrm{~S}$-sensitive channels are not restricted to cardiovascular system and could play different roles, as suggested by the evidence that the same inhibitory effect has been previously described in mouse pancreatic beta cells, affecting insulin secretion [22]. Moreover, a tissue-specific regulation of L-type calcium channels is likely to occur. Indeed, $\mathrm{H}_{2} \mathrm{~S}$ activates these channels in the nervous system $[30,36]$, while in other tissues (e.g. cardiovascular system or pancreatic cells) it exerts a negative regulation [15].

A number of questions, beyond the aim of the present study, remain open and deserve more detailed investigation. Here the conclusions are based on calcium imaging and pharmacological approaches. As such, the biophysical and molecular properties of L- and T-type channels in H9c2 cells, as well as their modulation by $\mathrm{H}_{2} \mathrm{~S}$ should be analyzed by electrophysiological (patch clamp) techniques to strengthen and extend our results.

Finally, this work unveils the ability of $\mathrm{H}_{2} \mathrm{~S}$ to affect, directly or indirectly, the function of several key channels in H9c2 cells, suggesting its housekeeping and multifunctional role in cell signaling (for a schematic overview see Fig. 6).

\section{Acknowledgements}

L.M and D.M. are supported by grants from MIUR.

\section{References}

1 Zhang Y, Du Y, Le W, Wang K, Kieffer N, Zhang J: Redox control of the survival of healthy and diseased cells. Antioxid Redox Signal 2011;15:2867-2908.

2 Elias-Miro M, Bibiana Jimenez-Castro M, Rodes J, Peralta C: Current knowledge on oxidative stress in hepatic ischemia/reperfusion. Free Radic Res 2013;47:555-568.

-3 Olmez I, Ozyurt H: Reactive oxygen species and ischemic cerebrovascular disease. Neurochem Int 2012;60:208-212.

4 Raedschelders K, Ansley DM, Chen DD: The cellular and molecular origin of reactive oxygen species generation during myocardial ischemia and reperfusion. Pharmacol Ther 2012;133:230-255.

-5 Wen Y-D, Wang H, Kho S-H, Rinkiko S, Sheng X, Shen H-M, Zhu YZ: Hydrogen sulfide protects HUVECs against hydrogen peroxide induced mitochondrial dysfunction and oxidative stress. PLoS One 2013;8:e53147.

6 Becker LB: New concepts in reactive oxygen species and cardiovascular reperfusion physiology. Cardiovasc Res 2004;61:461-470.

7 Gottlieb RA: Cell death pathways in acute ischemia/reperfusion injury. J Cardiovasc Pharmacol Ther 2011;16:233-238.

8 Van Golen RF, van Gulik TM, Heger M: Mechanistic overview of reactive species-induced degradation of the endothelial glycocalyx during hepatic ischemia/reperfusion injury. Free Radic Biol Med 2012;52:1382-1402.

-9 Bond CE, Greenfield SA: Multiple cascade effects of oxidative stress on astroglia. Glia 2007;55:1348-1361.

10 Weisfeldt ML, Zweier J, Ambrosio G, Becker LC, Flaherty JT: Evidence that free radicals result in reperfusion injury in heart muscle. Basic Life Sci 1988;49:911-919.

-11 Dringen R: Oxidative and antioxidative potential of brain microglial cells. Antioxidants redox Signal 2005; 7:1223-1233.

-12 Osipov RM, Robich MP, Feng J, Liu Y, Clements RT, Glazer HP, Sodha NR, Szabo C, Bianchi C, Sellke FW: Effect of hydrogen sulfide in a porcine model of myocardial ischemia-reperfusion: comparison of different administration regimens and characterization of the cellular mechanisms of protection. J Cardiovasc Pharmacol 2009;54:287-297.

13 Pan TT, Neo KL, Hu LF, Yong QC, Bian JS: H2S preconditioning-induced PKC activation regulates intracellular calcium handling in rat cardiomyocytes. Am J Physiol 2008;294:C169-177. 
14 Mancardi D, Penna C, Merlino A, Del Soldato P, Wink DA, Pagliaro P: Physiological and pharmacological features of the novel gasotransmitter: hydrogen sulfide. Biochim Biophys Acta 2009;1787:864-872.

15 Tang G, Wu L, Wang R: Interaction of hydrogen sulfide with ion channels. Clin Exp Pharmacol Physiol 2010;37:753-763.

16 Zhao W, Zhang J, Lu Y, Wang R: The vasorelaxant effect of H(2)S as a novel endogenous gaseous K(ATP) channel opener. EMBO J 2001;20:6008-6016.

17 Munaron L, Avanzato D, Moccia F, Mancardi D: Hydrogen sulfide as a regulator of calcium channels. Cell Calcium 2013;53:77-84.

18 Fauconnier J, Meli AC, Thireau J, Roberge S, Shan J, Sassi Y, Reiken SR, Rauzier JM, Marchand A, Chauvier D, Cassan C, Crozier C, Bideaux P, Lompré AM, Jacotot E, Marks AR, Lacampagne A: Ryanodine receptor leak mediated by caspase-8 activation leads to left ventricular injury after myocardial ischemia-reperfusion. Proc Natl Acad Sci U S A 2011;108:13258-13263.

- 19 Komniski MS, Yakushev S, Bogdanov N, Gassmann M, Bogdanova A: Interventricular heterogeneity in rat heart responses to hypoxia: the tuning of glucose metabolism, ion gradients, and function. Am J Physiol 2011;300:H1645-1652.

20 Qi H, Cao Y, Huang W, Liu Y, Wang Y, Li L, Liu L, Ji Z, Sun H: Crucial Role of Calcium-Sensing Receptor Activation in Cardiac Injury of Diabetic Rats. PLoS One 2013;8:e65147.

21 Moccia F, Bertoni G, Pla AF, Dragoni S, Pupo E, Merlino A, Mancardi D, Munaron L, Tanzi F: Hydrogen sulfide regulates intracellular $\mathrm{Ca}^{2+}$ concentration in endothelial cells from excised rat aorta. Curr Pharm Biotechnol 2011;12:1416-1426.

22 G. Tang, L. Zhang, G. Yang, L. Wu RW: Hydrogen sulfide-induced inhibition of L-type Ca2+ channels and insulin secretion in mouse pancreatic beta cells. Diabetologia 2013;56:533-541.

23 Zhang R, Sun Y, Tsai H, Tang C, Jin H, Du J: Hydrogen Sulfide Inhibits L-Type Calcium Currents Depending upon the Protein Sulfhydryl State in Rat Cardiomyocytes. PLoS One 2012;7:e37073.

24 Wang R, Karpinski E PP: Two types of voltage-dependent calcium channel currents and their modulation by parathyroid hormone in neonatal rat ventricular cells. J Cardiovasc Pharmacol. 1991;17:990-8.

-25 Lee JH, Gomora JC, Cribbs LL, Perez-Reyes E: Nickel block of three cloned T-type calcium channels: low concentrations selectively block alpha1H. Biophys J 1999;77:3034-3042.

26 Wang R: Two's company, three's a crowd: can H2S be the third endogenous gaseous transmitter? FASEB J 2002;16:1792-1798.

27 Wang R: Physiological implications of hydrogen sulfide: a whiff exploration that blossomed. Physiol Rev 2012;92:791-896.

28 Sekiguchi F, Miyamoto Y, Kanaoka D, Ide H, Yoshida S, Ohkubo T, Kawabata A: Endogenous and exogenous hydrogen sulfide facilitates T-type calcium channel currents in Cav3.2-expressing HEK293 cells. Biochem Biophys Res Commun 2014;445:225-229.

-29 Okubo K, Matsumura M, Kawaishi Y, Aoki Y, Matsunami M, Okawa Y, Sekiguchi F, Kawabata A: Hydrogen sulfide-induced mechanical hyperalgesia and allodynia require activation of both $\mathrm{Ca}(\mathrm{v}) 3.2$ and TRPA1 channels in mice. Br J Pharmacol 2012;166:1738-1743.

-30 Maeda Y, Aoki Y, Sekiguchi F, Matsunami M, Takahashi T, Nishikawa H, Kawabata A: Hyperalgesia induced by spinal and peripheral hydrogen sulfide: evidence for involvement of Cav3.2 T-type calcium channels. Pain 2009;142:127-132.

-31 Elies J, Dallas M, Scragg JL, Boyle JP, Peers C: Inhibition of recombinant T-type Ca ${ }^{2+}$ channels by hydrogen sulfide. Nitric Oxide 2013;31:S27-S28.

-32 Fiorio Pla A, Grange C, Antoniotti S, Tomatis C, Merlino A, Bussolati B, Munaron L: Arachidonic acid-induced $\mathrm{Ca} 2+$ entry is involved in early steps of tumor angiogenesis. Mol Cancer Res 2008;6:535-545.

-33 Zhao Y, Huang H, Jiang Y, Wei H, Liu P: Unusual localization and translocation of TRPV4 protein in cultured ventricular myocytes of the neonatal rat. Eur J Histochem 2012;56:e32.

-34 Watanabe H, Iino K, Ohba T IH: Possible involvement of TRP channels in cardiac hypertrophy and arrhythmia. Curr Top Med Chem 2013;13:283-294.

-35 Gao H, Wang F, Wang W, Makarewich CA, Zhang H, Kubo H, Berretta RM, Barr LA, Molkentin JD HS: Ca ${ }^{2+}$ influx through L-type $\mathrm{Ca}^{2+}$ channels and transient receptor potential channels activates pathological hypertrophy signaling. J Mol Cell Cardiol 2012;53:657-667.

-36 Nagai Y, Tsugane M, Oka J, Kimura H: Hydrogen sulfide induces calcium waves in astrocytes. FASEB J 2004;18:557-559. 